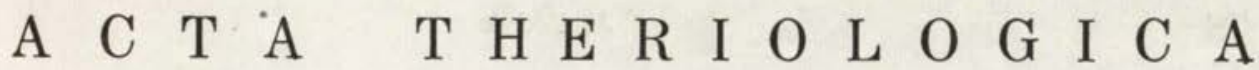

VOL. 19, 27: 403-427. BIAŁOWIEŻA November, 1974

Anna FEDYK

\section{Gross Body Composition in Postnatal Development of the Bank Vole. II. Differentiation of Seasonal Generations *}

[With 6 Tables \& 8 Figs.]

Changes in the rate of increase in the proportions of gross body composition accompanying the development of the spring and autumn generations were determined. Significant differences were found in these animals both in the rate of accumulation of fat and also the rate of increase of the components of the fat-free body mass (FFB). Bank voles of the spring generation attain chemical maturity by the 35-40th day of life, but the autumn generation does not reach this stage until the 110-120th day of life. Voles of the autumn generation are physiologically younger than of the spring generation of comparable age. It is suggested that there may be a "specific metamorphosis of generations $\approx$ in rodents as a mechanism of cyclomorphism.

\section{INTRODUCTION}

Data obtained from keeping small mammals in captivity have provided information on the characteristic features of their development and growth. The parameters determined under these conditions are not, however, characteristic of the species when living under the influence of a large number of natural habitat conditions and no less complex intrapopulation factors. It is on this accout that studies on the seasonal variations in skull height and body dimensions in Soricidae (D e h n el, 1949; 1950; B orowski \& Dehnel, 1953) supplied the stimulus for numerous later studies on seasonal variation in small mammals, which have shown that, for insectivores and rodents, many parameters, both morphological and physiological are affected by cyclic changes in weather conditions. A further stages in studies on seasonal variation was the discovery of the relationship between the animal rate of development

* Praca została zrealizowana w ramach problemu węzłowego 09.1.7. koordynowanego przez Instytut Ekologii PAN. 
and the season in which it was born. The rate of growth of rodents born at the beginning of the reproductive season is more rapid than that of individuals born later. A particularly distinct differentiation in growth rate is evident when extreme litters from one reproductive season are compared. Individuals born at the beginning of the reproductive season, forming the spring generation or first spring cohort, reach their maximum weight when 3-4 months old, whereas in individuals born at the end of the reproductive season (autumn generation, the final cohort in the given reproduction season) there is an inhibition of growth at the age of $1^{1 / 2}-2$ monts, lasting until the spring of the next calendar year (Schwarz, Pokrovski, Istchenko, Ovtchinnikova \&

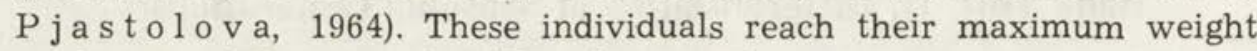
at the age of $8-9$ months $(\mathrm{Z} \mathrm{e} \mathrm{j} \mathrm{d} \mathrm{a,} \mathrm{1971).}$

The term "seasonal generation « suggest that one generation is the parent generation a subsequent one born in a different season of the year. At first it was used in scientific literature only to indicate the existence of a group of characters differentiating individuals born at different times of the year (A d a m c zew ska, 1961; $\mathrm{Schwarz}$ et al., 1964). It was also used in later studies to define animals born in a given time interval, without investigating the relationships between generations distinguished in this way (eg. Olenev, 1964: Pokrovski, 1966; 1971; Pokrovski \& Ovtchinnikova, 1967; Anderson, 1970; Adamczewska-Andrzejewska, 1971). Although knowledge has been obtained on the relationships connecting litters and appering during the reproductive season in many rodents, the basis for allocating an individual to the appriopriate generation continues to be its date of birth (Schwarz, Bol'shakov, Olenev \& Pjastolova, 1969/70), and it is therefore more correct to use the term "cohort « to define the group of individuals born over a given period of time (Gliwicz, Andrzejewski, Bujalska \& Petrusewicz, 1968, Zejda, 1971).

In the present study, however, the term sseasonal generation « has been used to indicate animals born at the beginning and end of the reproductive season, over period of time longer than that accepted for one cohort, without taking relationships into considerations.

Seasonal generations differ in respect of a large number of features and according to Anderson (1970) whave seasonal phenotypes with distinctive behavioural, physiological, morphological and genetical characteristics, which have different ecological and evolutionary roles and occupy different habitats «. The autor gives the name cyclomorphic to rodents characterized by such features.

C. glareolus can also be considered as a cyclomorphic species, since its cohorts or seasonal generations are characterized by differences in rate of growth and the rapidity with which sexual maturity is reached. Their ecological longevity is also different and consequently the part they play in maintaining the biological continuity of the species is also differentiated (inter alia K u bi k, 1965, Gliw ic z et al., 1968; P u cek, Ryszkowski \& Zejda, 1969/70, Hyvärinen \& Heikura, 
1971; Tupikova \& Konovalova, 1971; Z ejda, 1971; Kaik u$\mathrm{s}$ a 10,1972 ). It has been also shown that the mitotic activity of the epithelial tissues is different in exterme seasonal generations (A m st islavskaja, 1970), which confirms the suggestions made earlier by $\mathrm{Schwarz}$ et al. (1964) as to the prolongation of the period of physiological immaturity in the late seasonal generations. This prolongation of youth in animals born at the end of the reproductive season is connected with the inhibition of development during the winter. The rate of growth during the early part of postnatal development is uniform in representatives of all cohorts $(\mathrm{Zejda}, 1971)$, but it is not known whether the uniform increase in body mass of bank voles from extreme generations is accompanied by uniform changes in the proportions of gross body composition.

The purpose of the present study was to examine changes in amounts and proportions of the gross body composition during postnatal development in extreme seasonal generations of Clethrionomys glareolus ( $\mathrm{S} \mathrm{chreber}, 1870)$. A knowledge of the protein and water content of the animal's bodies, the quotient of which is the index of physiological age (see Bailey, Kitts \& Wood, 1960), made it possible to compare the physiological age of individuals from the two generations.

\section{MATERIAL AND METHODS}

On account of the difficulty in obtaining young bank voles of known absolute age from the field, wild voles were caught, kept in pairs in the laboratory and their first generation analysed, treating it as wild. The parent animals were caught in Tilio-Carpinetum and Fraxino-Ulmetum tree stands in the Białowieża National Park. The animals were trapped before the start of the reproductive season (March - May 1971 and 1972) and at the end of summer and in early autumn (end of July - September 1971).

The parent pairs were kept in a cage with their progeny for 21 days, after which the young were taken from their parents and each litter kept separately. The two generations had a uniform, artificially regulated, 16-hour light rhythm in the laboratory and constant access to drinking water. They were fed ad libitum on a diet of oats, beets, carrots and grasses during the growing season. When grass stopped growing at the beginning of November there was a change in the voles' diet. While all individuals of the spring generation were supplied with grass until the time they were killed, individuals of the autumn generation were deprived of green food at different ages. Those born earliest (in the second half of August) and kept in captivity for four months were given green food for $2 \frac{1}{2}$ months of their lives. In order to understand any different effect due to greens in the diet on the rate of growth of bank voles 10 pairs of parents caught in May and their progeny were kept on a diet without the addition of grass.

The young animals were analysed for body water, protein, fat and minerals by the methods described previously (F e dy k, 1974 a), taking animals from 1 to 120 days old for these analyses. Basic components were defined in animals of 
definite age: from 1 to 60 days old in 5-day intervals, and from 70 to 120 days old, in 10-day intervals. In all, 193 individuals of the spring generation, 112 individuals of the autumn generation and 35 individuals kept on a diet not including grass were analysed.

The results were elaborated statistically, describing the relations between body weight (eviscerated body) and fat content by straight-line regression equations, while equations of multiple regression were used for describing relationships within fat-free body mass (after Elandt, 1964).

In order to emphasise that the average rate of growth is the result of changes differing in time in the ratios of the components of gross body composition, the above relations were described by regression equations over a 4-month period of development and in several stages of this process. Four stages of development were distinguished: I. $1-20$, II. $25-40$, III. $45-60$ and IV. $70-120$ days old. The first of the above stages corresponds to the period the young remain with the mother. The final days of the next three stages correspond to the days on which the ratio of $F F B$ components was determined us unchangeable in the representatives of the spring generation, laboratory-bred voles (see Fedyk, 1974a) and autumn generation.

All the equations of regression were subjected to a test which consisted of checking the significance of the relations between themselves ( $t$-Student test) and a comparison of the significance of differences between the groups or pairs of equations ( $F$-Snedecor test). In order to illustrate equations of multiple regression in diagramatic form equations of partial regressions (after Marszałkowicz, 1966) were caltulated from them.

\section{RESULTS}

\section{Rate of Growth}

On account of the great accumulation of fat in bank voles of the spring generation over the age of 90 days (about $4.5 \mathrm{~g}$ of fat, forming over $60 \%$ of the dry mass) and their complete lack of activity, the rate of growth of the seasonal generations was examined during the first three months of postnatal development. During this period the body weight of voles born at the start of the reproductive season increases by eight times. This increase in body mass is due to an almost 50 -fold increase in fat, a 14-fold increase in protein and minerals and a 6-fold increase in body water in comparison with the weight of these components on the day of birth. Bank voles of the autumn generation, however, increase their mass by over 7 times as much (by $646 \%$ ), this increase consisting of as almost 29-fold increase in protein mass and a 5 -fold increase in body water (Table 1, Fig. 1). The average rate of increase in body mass is almost uniform in the generations compared during the first three months of life $(0.140 \mathrm{~g} /$ day in the spring generation and $0.137 \mathrm{~g} /$ day in the autumn generation). In comparable shorter periods of development the values of this parameter are different. The rate of increase in body mass during the first 20 days of life is $0.19 \mathrm{~g} / \mathrm{day}$, and 
Table 1

Eviscerated body weight and gross body composition in postnatal development of seasonal generations of $C$. glareolus. In vertical colums: 1 - average value - standard deviation; 2 - coefficient of variation; 3 - percentage content in relation to body weight. Upper line relates to spring generation, lower to autumn generation.

\begin{tabular}{|c|c|c|c|c|c|c|c|c|c|c|c|c|c|c|c|c|}
\hline \multirow[t]{2}{*}{$\begin{array}{l}\text { Age, } \\
\text { days }\end{array}$} & \multirow[t]{2}{*}{$\mathrm{N}$} & \multicolumn{2}{|c|}{ Body weight } & \multicolumn{3}{|c|}{ Fat } & \multicolumn{3}{|c|}{ Water } & \multicolumn{3}{|c|}{ Protein } & \multicolumn{3}{|c|}{ Ash } & \multirow{2}{*}{$\begin{array}{c}\begin{array}{c}\text { Protein: } \\
\text { Water } \\
\text { ratio }\end{array} \\
1\end{array}$} \\
\hline & & 1 & 2 & 1 & 2 & 3 & 1 & 2 & 3 & 1 & 2 & 3 & 1 & 2 & 3 & \\
\hline 1 & $\begin{array}{l}17 \\
14\end{array}$ & $\begin{array}{l}1.739 \pm .125 \\
1.881 \pm .288\end{array}$ & $\begin{array}{r}7.2 \\
15.3\end{array}$ & $\begin{array}{l}.047 \pm .014 \\
.129 \pm .032\end{array}$ & $\begin{array}{l}29.9 \\
24.4\end{array}$ & $\begin{array}{l}2.7 \\
6.9\end{array}$ & $\begin{array}{l}1.443 \pm .011 \\
1.555 \pm .135\end{array}$ & $\begin{array}{r}.8 \\
8.7\end{array}$ & $\begin{array}{l}83.0 \\
82.7\end{array}$ & $\begin{array}{l}.199 \pm .017 \\
.162 \pm .028\end{array}$ & $\begin{array}{r}8.7 \\
17.4\end{array}$ & $\begin{array}{r}11.4 \\
8.6\end{array}$ & $\begin{array}{l}.037 \pm .024 \\
.032 \pm .002\end{array}$ & $\begin{array}{r}66.4 \\
8.6\end{array}$ & $\begin{array}{l}2.1 \\
1.7\end{array}$ & $\begin{array}{l}.128 \\
.104\end{array}$ \\
\hline 10 & $\begin{array}{l}22 \\
10\end{array}$ & $\begin{array}{l}3.946 \pm .611 \\
4.276 \pm .212\end{array}$ & $\begin{array}{r}15.5 \\
4.9\end{array}$ & $\begin{array}{l}.327 \pm .081 \\
.367 \pm .120\end{array}$ & $\begin{array}{l}24.6 \\
32.6\end{array}$ & $\begin{array}{l}8.3 \\
8.6\end{array}$ & $\begin{array}{l}2.949 \pm .142 \\
3.231 \pm .123\end{array}$ & $\begin{array}{l}4.8 \\
3.8\end{array}$ & $\begin{array}{l}74.5 \\
75.6\end{array}$ & $\begin{array}{l}.548 \pm .140 \\
.585 \pm .048\end{array}$ & $\begin{array}{l}25.6 \\
14.0\end{array}$ & $\begin{array}{l}13.9 \\
13.7\end{array}$ & $\begin{array}{l}.086 \pm .017 \\
.065 \pm .000\end{array}$ & 20.1 & $\begin{array}{l}2.2 \\
1.5\end{array}$ & $\begin{array}{l}.192 \\
.178\end{array}$ \\
\hline 20 & $\begin{array}{l}17 \\
10\end{array}$ & $\begin{array}{l}5.364 \pm 1.623 \\
7.539 \pm .685\end{array}$ & $\begin{array}{r}30.2 \\
9.1\end{array}$ & $\begin{array}{l}.471 \pm .096 \\
.722 \pm .197\end{array}$ & $\begin{array}{l}20.4 \\
27.3\end{array}$ & $\begin{array}{l}8.8 \\
9.6\end{array}$ & $\begin{array}{l}4.470 \pm .395 \\
5.226 \pm .391\end{array}$ & $\begin{array}{l}8.8 \\
7.5\end{array}$ & $\begin{array}{l}83.3 \\
69.3\end{array}$ & $\begin{array}{l}1.175 \pm .125 \\
1.337 \pm .097\end{array}$ & $\begin{array}{r}10.7 \\
7.2\end{array}$ & $\begin{array}{l}21.9 \\
17.7\end{array}$ & $\begin{array}{l}.176 \pm .010 \\
.236 \pm .017\end{array}$ & $\begin{array}{l}5.7 \\
7.3\end{array}$ & $\begin{array}{l}3.3 \\
3.1\end{array}$ & $\begin{array}{l}.263 \\
.256\end{array}$ \\
\hline $30^{*}$ & 7 & $12.115 \pm 1.904$ & 15.7 & $.663 \pm .202$ & 30.4 & 5.2 & $6.046 \pm 1.420$ & 23.5 & 49.9 & $1.973 \pm .281$ & 14.2 & 16.3 & $.321 \pm .051$ & 6.9 & 2.6 & .305 \\
\hline 40 & $\begin{array}{l}23 \\
10\end{array}$ & $\begin{array}{l}12.240 \pm 1.283 \\
11.284 \pm 2.751\end{array}$ & $\begin{array}{l}10.5 \\
24.4\end{array}$ & $\begin{array}{l}1.393 \pm .630 \\
1.813 \pm 1.008\end{array}$ & $\begin{array}{l}45.2 \\
55.6\end{array}$ & $\begin{array}{l}11.4 \\
16.1\end{array}$ & $\begin{array}{l}7.840 \pm .693 \\
7.141 \pm 1.030\end{array}$ & $\begin{array}{r}8.8 \\
14.4\end{array}$ & $\begin{array}{l}64.0 \\
63.3\end{array}$ & $\begin{array}{l}2.517 \pm .221 \\
1.911 \pm .876\end{array}$ & $\begin{array}{r}8.8 \\
45.8\end{array}$ & $\begin{array}{l}20.6 \\
16.9\end{array}$ & $\begin{array}{l}.415 \pm .057 \\
.357 \pm .053\end{array}$ & $\begin{array}{l}13.8 \\
14.8\end{array}$ & $\begin{array}{l}3.4 \\
3.2\end{array}$ & $\begin{array}{l}.323 \\
.268\end{array}$ \\
\hline 60 & $\begin{array}{l}13 \\
15\end{array}$ & $\begin{array}{l}12.650 \pm 2.360 \\
13.257 \pm 2.352\end{array}$ & $\begin{array}{l}18.6 \\
17.7\end{array}$ & $\begin{array}{l}2.537 \pm 1.387 \\
1.858 \pm 1.037\end{array}$ & $\begin{array}{l}54.7 \\
55.8\end{array}$ & $\begin{array}{l}20.1 \\
14.0\end{array}$ & $\begin{array}{l}7.310 \pm .945 \\
8.518 \pm 1.055\end{array}$ & $\begin{array}{l}12.9 \\
12.4\end{array}$ & $\begin{array}{l}57.8 \\
64.2\end{array}$ & $\begin{array}{l}2.370 \pm .316 \\
2.371 \pm .301\end{array}$ & $\begin{array}{l}13.4 \\
12.7\end{array}$ & $\begin{array}{l}18.7 \\
17.9\end{array}$ & $\begin{array}{l}.447 \pm .065 \\
.503 \pm .061\end{array}$ & $\begin{array}{l}14.5 \\
12.1\end{array}$ & $\begin{array}{l}3.5 \\
3.8\end{array}$ & $\begin{array}{l}.322 \\
.278\end{array}$ \\
\hline 90 & $\begin{array}{r}13 \\
9\end{array}$ & $\begin{array}{l}14.494 \pm 2.446 \\
14.041 \pm 1.972\end{array}$ & $\begin{array}{l}16.9 \\
14.0\end{array}$ & $\begin{array}{l}2.377 \pm 1.534 \\
3.731 \pm 1.277\end{array}$ & $\begin{array}{l}64.5 \\
34.2\end{array}$ & $\begin{array}{l}16.4 \\
26.6\end{array}$ & $\begin{array}{l}8.773 \pm 1.739 \\
7.700 \pm .867\end{array}$ & $\begin{array}{l}19.8 \\
11.2\end{array}$ & $\begin{array}{l}60.5 \\
54.9\end{array}$ & $\begin{array}{l}2.845 \pm .431 \\
2.120 \pm .218\end{array}$ & $\begin{array}{l}15.2 \\
10.3\end{array}$ & $\begin{array}{l}19.6 \\
15.1\end{array}$ & $\begin{array}{l}.520 \pm .085 \\
.491 \pm .057\end{array}$ & $\begin{array}{l}16.3 \\
11.7\end{array}$ & $\begin{array}{l}3.6 \\
3.5\end{array}$ & $\begin{array}{l}.324 \\
.276\end{array}$ \\
\hline - 1 & 7 & $12.901 \pm 2.190$ & 17.0 & $1.699 \pm .775$ & 45.6 & 13.2 & $8.120 \pm 1.430$ & 17.6 & 62.9 & $2.554 \pm .143$ & 5.6 & 19.8 & $.513 \pm .071$ & 13.9 & 4.0 & .315 \\
\hline
\end{tabular}

* Spring generation. ** Autumn generation. 
$0.75 \mathrm{~g} /$ day between the 20 th and 30 th day of life. During the second month of life the values of this parameter are reduced to 0.004 and during the third month of life rise again but only to $0.063 \mathrm{~g} / \mathrm{day}$. In the spring generation the most rapid increase in body mass takes place during the first 20 days of life, on average by $0.300 \mathrm{~g} /$ day, whereas during the subsequent 20 days of life it decreases to about $0.20 \mathrm{~g} /$ day, and during the third months of life decreases to $0.006 \mathrm{~g} /$ day. It must be emphasised that voles of the autumn generation are almost always

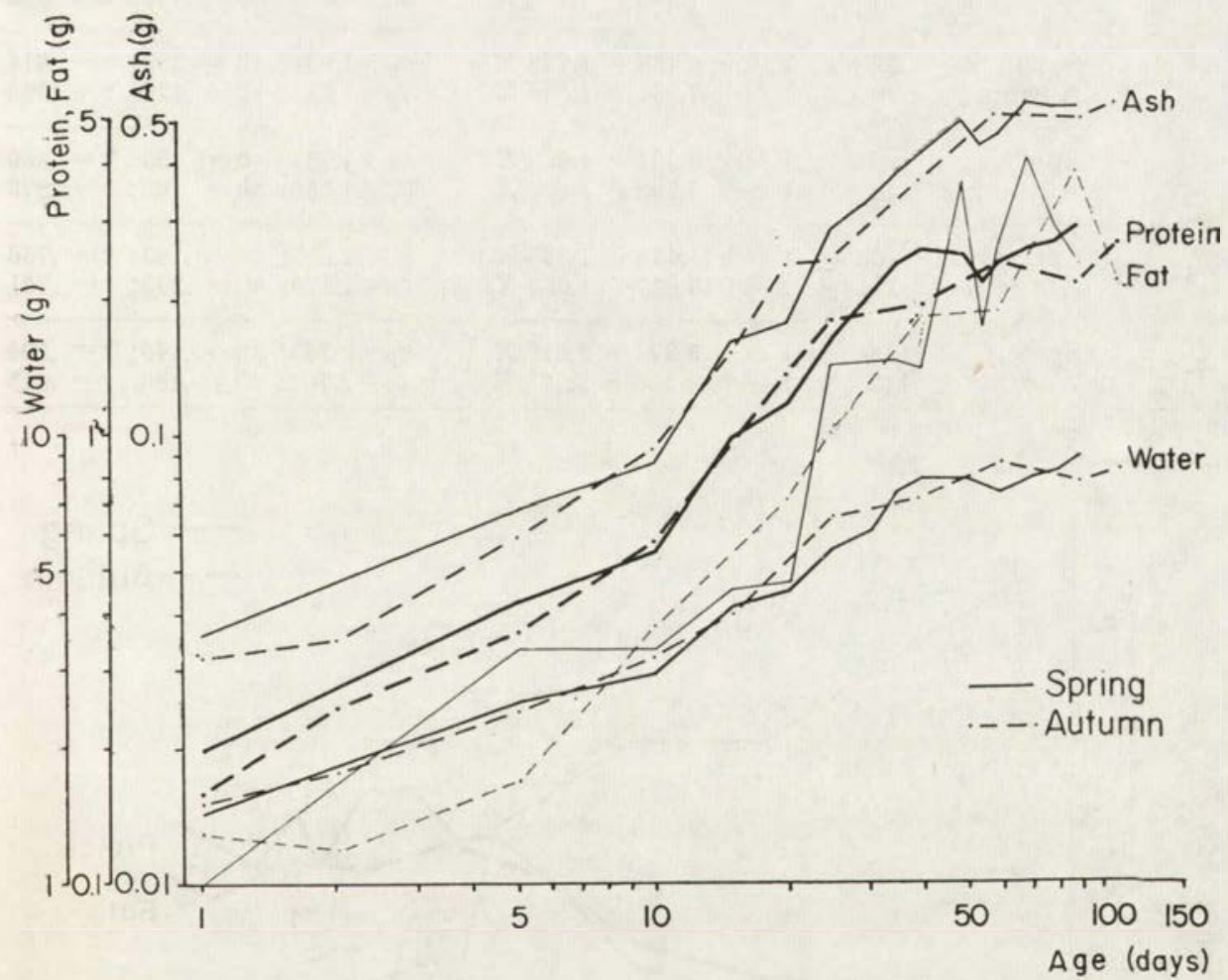

Fig. 1. Gross body composition of seasonal generations of C. glareolus in postnatal development.

heavier than the individuals of corresponding age belonging to the spring generation (except for the 40th and 90th day of life) (cf. Table 1).

\section{Fat Accumulation}

The rate of adiposis undoubtedly affects differentiation in rate of mass increase during postnatal development. With respect to body fat the seasonal generations differ as early as the day of brith. The bodies of voles born at the end of the reproductive season were shown to contain 
Table 2

Relation between fat accumulation and eviscerated body weight in postnatal development of seasonal generations of C. glareolus. Equations for age groups I, II, III and IV refer to the various stages of development. The last two equations describe the rate of fat accumulation during the first four months of life in bank voles.

\begin{tabular}{|c|c|c|c|c|}
\hline $\begin{array}{l}\text { Age } \\
\text { group }\end{array}$ & Generation & $\mathrm{N}$ & $\mathrm{Y}=$ body weight, & $X=$ fat \\
\hline I & $\begin{array}{l}\text { Spring } \\
\text { Autumn }\end{array}$ & $\begin{array}{l}84 \\
54\end{array}$ & $\begin{array}{l}\mathrm{Y}=+2.254+6.070 \mathrm{X} \\
\mathrm{Y}=+1.503+7.986 \mathrm{X}\end{array}$ & $\begin{array}{l}s_{y}=1.089 ; s b=.523 ; r=.788 \\
s_{y}=.806 ; s b=.433 ; r=.920\end{array}$ \\
\hline II & $\begin{array}{l}\text { Spring } \\
\text { Autumn }\end{array}$ & $\begin{array}{l}57 \\
18\end{array}$ & $\begin{array}{l}Y=+8.458+1.785 X \\
Y=+7.757+1.894 X\end{array}$ & $\begin{array}{l}s_{y}=1.837 ; s b=.309 ; r=.614 \\
s_{y}=.225 ; s b=.125 ; r=.960\end{array}$ \\
\hline III & $\begin{array}{l}\text { Spring } \\
\text { Autumn }\end{array}$ & $\begin{array}{l}26 \\
15\end{array}$ & $\begin{array}{l}Y=+9.091+1.358 X \\
Y=+9.798+1.862 X\end{array}$ & $\begin{array}{l}s_{y}=1.551 ; s b=.150 ; r=.880 \\
s_{y}=1.556 ; s b=.198 ; r=.870\end{array}$ \\
\hline IV & $\begin{array}{l}\text { Spring } \\
\text { Autumn }\end{array}$ & $\begin{array}{l}26 \\
25\end{array}$ & $\begin{array}{l}Y=+11.463+1.335 X \\
Y=+10.827+1.050 X\end{array}$ & $\begin{array}{l}s_{y}=1.817 ; s b=.183 ; r=.756 \\
s_{y}=1.178 ; s b=.293 ; r=.741\end{array}$ \\
\hline I-IV & $\begin{array}{l}\text { Spring } \\
\text { Autumn }\end{array}$ & $\begin{array}{l}193 \\
112\end{array}$ & $\begin{array}{l}Y=+5.371+2.616 X \\
Y=+4.298+3.121 X\end{array}$ & $\begin{array}{l}s_{y}=2.743 ; s b=.140 ; r=.804 \\
s_{y}=2.701 ; s b=.188 \quad r=.945\end{array}$ \\
\hline
\end{tabular}

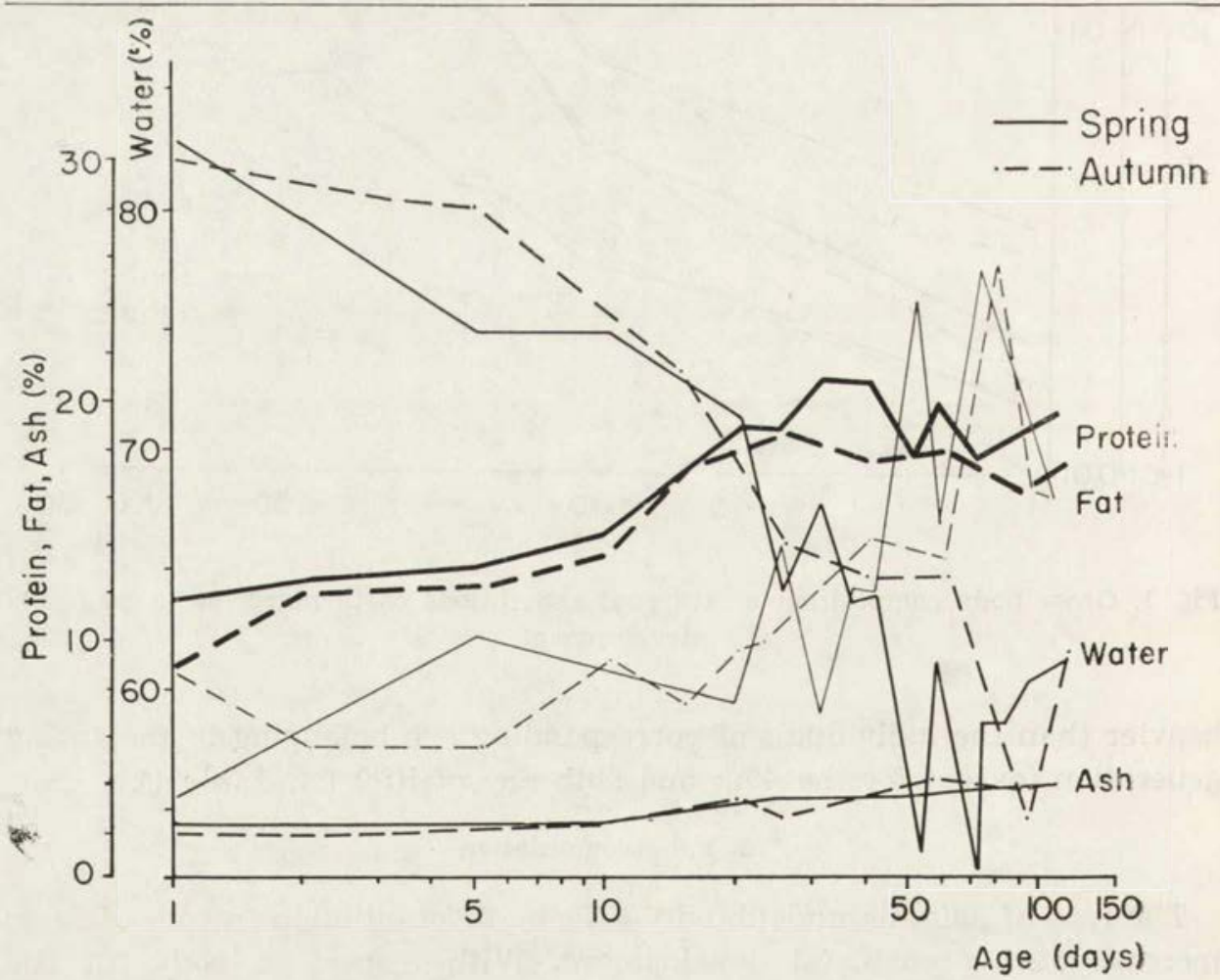

Fig. 2. Average gross body composition in percentages of $C$. glareolus of seasonal generations in postnatal development. 
$175 \%$ more fat than these of individuals of the spring generation (Table 1). Although, during development, the amounts and ratio of fat in voles' bodies is subject to fluctuation, it is possible to perceive a tendency towards an increase in fat mass with increased body mass (Table 1, Fig. 2). The greatest fat accumulation is found in 60-day old voles of the spring generation and 90 -day old voles of the autumn generation.

The relationships between body fat and body weight are statistically significant (Table 2). The average rate of fat accumulation during the first four months of life differs to a statistically significant degree in the

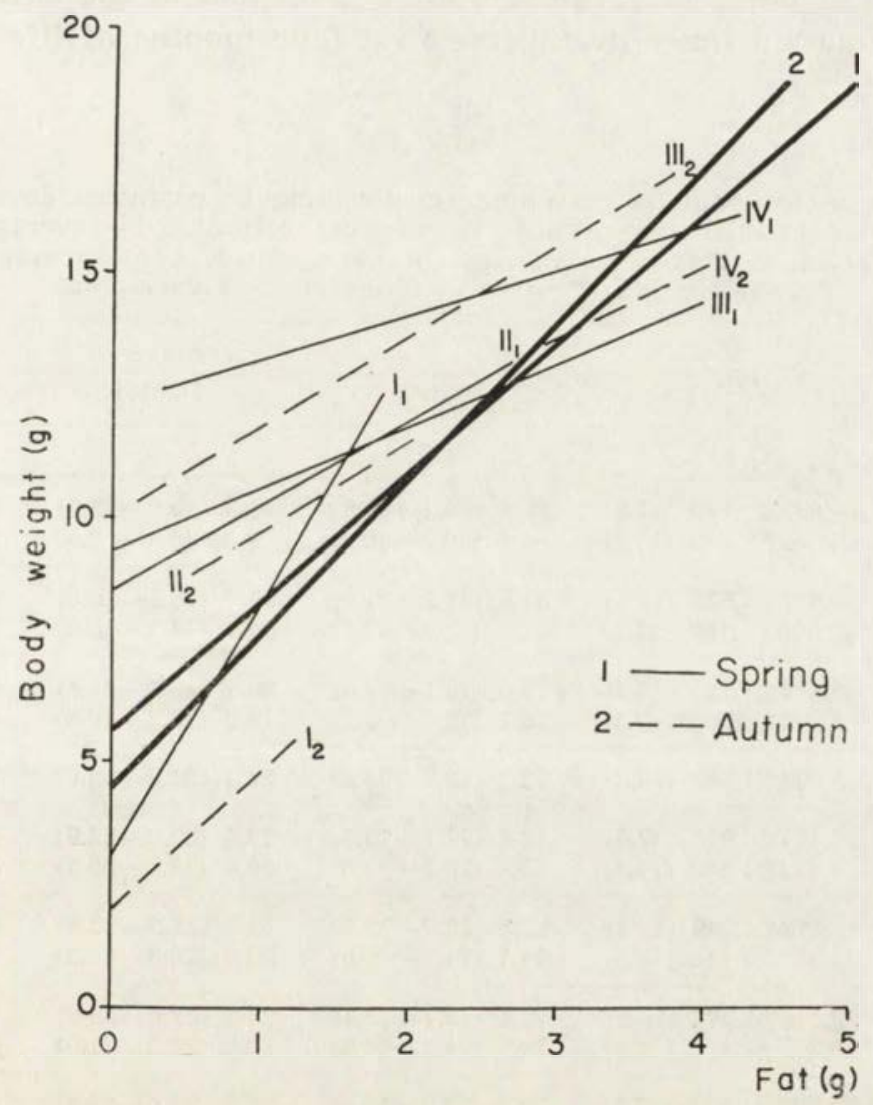

Fig. 3. Relation between fat accumulation and body weight of seasonal generations of C. glareolus in postnatal development.

generations compared and it is higher in voles born at the end of the reproductive season. The rate of fat accumulation is also higher in them during the first three stages of development ( $1-60$ day of life). Between the 70 th and 120th day of life the rate of increase of fat is very much greater in voles of the spring generation, which is connected with 
excesive adiposis, referred to above, in voles during the fourth month of life (Table 2). It must be emphasised that the mathematical relationship between body weight and amount of fat when comparing the generations and also in comparing the rate of fat deposit in different age groups of one generations, are significantly different in all cases (Fig. 3).

\section{Fat-free Body Mass $(F F B)$}

Growth is essentially an increase a FFB mass. This increases in voles of the spring generation by more than 7 times and in the autumn generation by almost 6 times during the first four months of life (Table 3).

Table 3

Fat-free body weight and its percentage composition in postnatal development of C. glareolus of seasonal generations. In vertical columns: 1-average value standard deviation, in brackets coefficient of variation; $2,3,4$-average values in percentages, in brackets - range of their variations.

\begin{tabular}{|c|c|c|c|c|c|c|}
\hline \multirow{2}{*}{$\begin{array}{l}\text { Age, } \\
\text { days }\end{array}$} & & \multirow{2}{*}{$F F B$} & \multicolumn{4}{|c|}{ Percentage of } \\
\hline & & & & Water & Protein & Ash \\
\hline & & 1 & & 2 & 3 & 4 \\
\hline \multirow[t]{2}{*}{1} & S & $1.692 \pm .129 \quad(7.6)$ & 85.3 & $(84.1-86.5)$ & $11.8(10.0-12.8)$ & $2.2(1.7-2.6)$ \\
\hline & & $1.752 \pm .313(17.9)$ & 88.8 & $(88.3-89.1)$ & $9.3 \quad(8.9-9.5)$ & $1.9(1.8-2.0)$ \\
\hline \multirow{2}{*}{10} & $\mathrm{~S}$ & $3.612 \pm .525$ (14.5) & 81.6 & $(81.2-81.9)$ & $15.7(15.2-16.0)$ & $2.4(2.2-2.8)$ \\
\hline & A & $3.909 \pm .163$ & 82.7 & $(82.2-83.1)$ & $14.7(14.1-15.0)$ & $2.3(2.2-2.4)$ \\
\hline \multirow{2}{*}{20} & $\mathrm{~S}$ & $5.834 \pm .525 \quad(9.0)$ & 76.6 & $(76.1-77.0)$ & $20.1(19.4-21.5)$ & $3.0(2.2-2.3)$ \\
\hline & A & $6.817 \pm .506$ & 76.7 & $(76.4-77.2)$ & $19.6(19.0-19.9)$ & $3.5(3.0-3.6)$ \\
\hline 30 & $\mathbf{S}$ & $8.906 \pm 1.189$ & 72.7 & $(72.2-73.1)$ & $22.1(21.9-23.0)$ & $3.6(3.3-3.8)$ \\
\hline \multirow{2}{*}{40} & $\mathrm{~S}$ & $10.797 \pm .971 \quad(9.0)$ & 72.5 & $(72.1-73.0)$ & $23.4(22.8-23.9)$ & $3.8(3.3-4.6)$ \\
\hline & A & $9.472 \pm 1.369$ & 75.4 & $(75.2-75.6)$ & $20.0(19.5-20.5)$ & $3.8(3.6-4.0)$ \\
\hline \multirow{2}{*}{60} & $\mathrm{~S}$ & $10.113 \pm 1.289$ & 72.3 & $(72.0-72.8)$ & $23.3(22.9-23.8)$ & $4.4(3.4-5.0)$ \\
\hline & A & $11.398 \pm 1.414(12.4)$ & 74.7 & $(74.2-75.0)$ & $20.8(20.3-21.2)$ & $4.4(4.3-4.6)$ \\
\hline \multirow{2}{*}{90} & $\mathbf{S}$ & $12.116 \pm 1.973(16.3)$ & 72.4 & $(72.1-72.7)$ & $23.2(22.9-23.6)$ & $4.3(4.2-4.4)$ \\
\hline & A & $10.310 \pm 1.115(10.8)$ & 74.7 & $(74.2-74.9)$ & $20.6(20.3-21.0)$ & $4.8(4.3-5.7)$ \\
\hline 120 & A & $11.202 \pm 1.934(17.3)$ & 72.4 & $(72.0-73.0)$ & $22.8(21.4-23.7)$ & $4.6(4.3-5.7)$ \\
\hline
\end{tabular}

The ratio of body water, body protein and minerals included in the composition of the FFB differs in different stages of development (Table 4 and 5 , Fig. 4 and 5). The participation by body water in the increase in mass of the voles of the autumn generation is almost uniform in all stages of development, while in voles of the spring generation, during the period from the 25 to 40 th day of life the increase in FFB due to water 


\section{Table 4}

Relation between simultaneous effect of increase in body water $\left(X_{2}\right)$, minerals $\left(X_{3}\right)$ and protein $\left(X_{4}\right)$ on FFB increase $\left(X_{1}\right)$ in various stages of development and during four months of life of C. glareolus. Upper equation (S) describes the spring generation, lower (A) - autumn generation.

Age
group $\quad$ Multiple regression equations

I S $\quad X_{1}=-.0623+1.0716 X_{2}+2.0439 X_{3}+.5961 X_{4} \quad s y=.0412 ; s b_{2}=0186 ; s b_{3}=.3503 ; s b_{4}=.0571$

I A $\quad X_{1}=-.0354+1.0345 X_{2}+1.9585 X_{3}+.7336 X_{4} \quad s y=.0190 ; s b_{2}=.0114 ; s b_{3}=.2206 ; s b_{4}=.0482$

II $S \quad X_{1}=+.8833+.0094 X_{2}+3.0749 X_{3}+3.4895 X_{4} \quad s y=.2720 ; s b_{2}=.1003 ; s b_{3}=1.0197 ; s b_{4}=.2589$

II A $\quad X_{1}=-.0307+1.1229 X_{2}+.8712 X_{3}+.6143 X_{4} s y=.0059 ; s b_{2}=.1207 ; s b_{3}=.3572 ; s b_{4}=.4914$

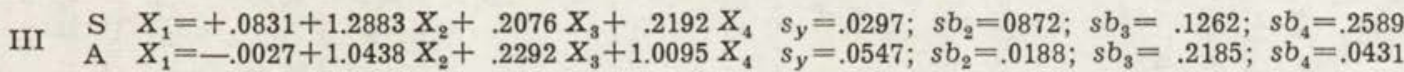

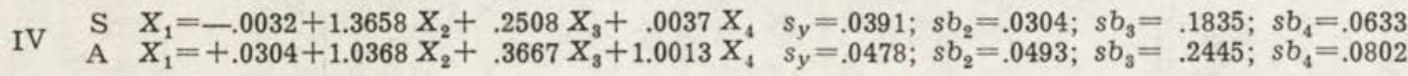

I-IV S $X_{1}=+.3919+.7236 X_{2}+1.0456 X_{3}+1.7089 X_{4} \quad s_{y}=.2377 ; s b_{2}=.0493 ; s b_{3}=.3789 ; s b_{4}=.1446$ A $\quad X_{1}=-.0372+1.0254 X_{2}+.6108 X_{3}+1.0126 X_{4} \quad s_{y}=.0325 ; s b_{2}=.0090 ; s b_{3}=.0653 ; s b_{4}=.0291$ 
is minimal in comparison with the other stages of development (Fig. 4). This affects the average rate for the four months of $F F B$ increase due to body water, this rate being significantly lower in voles of the spring generation than the autumn one (Fig. 4).

The rate of increase in the $F F B$ of the seasonal generations due to protein accumulation is more variable during postnatal development than is the increase due to water content. These differences are particularly distinct in voles of the spring generation, in which body protein in FFB increases most rapidly within the second age group (25-40 days of life). During the first 20 days of life the increase in body protein is almost five times smaller than during the second period of development.

\section{Table 5}

Equations of partial regression. Relations between one of $F F B$ components and $F F B$. Value of coefficient of regression between pair of variables (e.g., $\left.X_{1}-X_{2}\right)$ defines not only the actual effect of independent variable (e.g., $\left.X_{2}\right)$ on value of dependent variable $\left(e . g ., X_{1}\right)$ but also effect on this independent variables increasing parallel to each other $\left(X_{3}\right.$ and $\left.X_{4}\right)$. Upper line relates to spring generation, lower to autumn generation.

\begin{tabular}{rlll}
\hline $\begin{array}{c}\text { Age } \\
\text { group }\end{array}$ & $X_{1}=F F B ; \quad X_{2}=$ water; $\quad X_{3}=$ minerals; $\quad X_{4}=$ protein \\
\hline I $\begin{array}{l}X_{1}=.5507+1.0716 X_{2} \\
X_{1}=.5848+1.0345 X_{2}\end{array}$ & $\begin{array}{l}X_{1}=3.6889+2.0439 X_{3} \\
X_{1}=1.7379+1.9585 X_{3}\end{array}$ & $\begin{array}{l}X_{1}=3.5082+.5962 X_{4} \\
X_{1}=3.2204+.7336 X_{4}\end{array}$ \\
\hline II $\begin{array}{l}X_{1}=9.4190+.0094 X_{2} \\
X_{1}=1.3543+1.1229 X_{2}\end{array}$ & $\begin{array}{l}X_{1}=8.3841+3.0749 X_{3} \\
X_{1}=8.7543+.8712 X_{3}\end{array}$ & $\begin{array}{l}X_{1}=7.8935+3.4895 X_{4} \\
X_{1}=7.9835+.6143 X_{4}\end{array}$ \\
\hline III $\begin{array}{l}X_{1}=.6860+1.2883 X_{2} \\
X_{1}=2.5066+1.0438 X_{2}\end{array}$ & $\begin{array}{l}X_{1}=9.8879+.2076 X_{3} \\
X_{1}=11.2825+.2292 X_{3}\end{array}$ & $\begin{array}{l}X_{1}=9.4736+.2192 X_{4} \\
X_{1}=9.0039+1.0095 X_{4}\end{array}$ \\
\hline IV $\begin{array}{l}X_{1}=.1380+1.3658 X_{2} \\
X_{1}=2.6347+1.0368 X_{2}\end{array}$ & $X_{1}=11.4335+.2508 X_{3}$ & $X_{1}=11.5547+.0037 X_{4}$ \\
\hline I-IV $\begin{array}{l}X_{1}=3.4330+.7236 X_{2} \\
X_{1}=1.4591+1.0254 X_{2}\end{array}$ & $X_{1}=4.4413+1.0456 X_{3}$ & $X_{1}=6.4452+.6108 X_{3}$ & $X_{1}=6.6587+1.7089 X_{4}$ \\
\hline
\end{tabular}

After the fortieth day of life the rate of increase in protein slackens abruptly, resulting in its participation in the increase of $F F B$ mass being minimal during the fourth month of life. In voles of the autumn generation, however, protein increases at a completly different but more even rate. During the period from the 1st to 40 th day of life a increase by one unit of protein corresponds to an increase in $F F B$ by $0.60-0.70$ of a unit. During the remaining period a unit increase in protein corresponds to a unit increase in $F F B$. The average rate for the four months of protein accumulation in the $F F B$ for voles of the autumn 


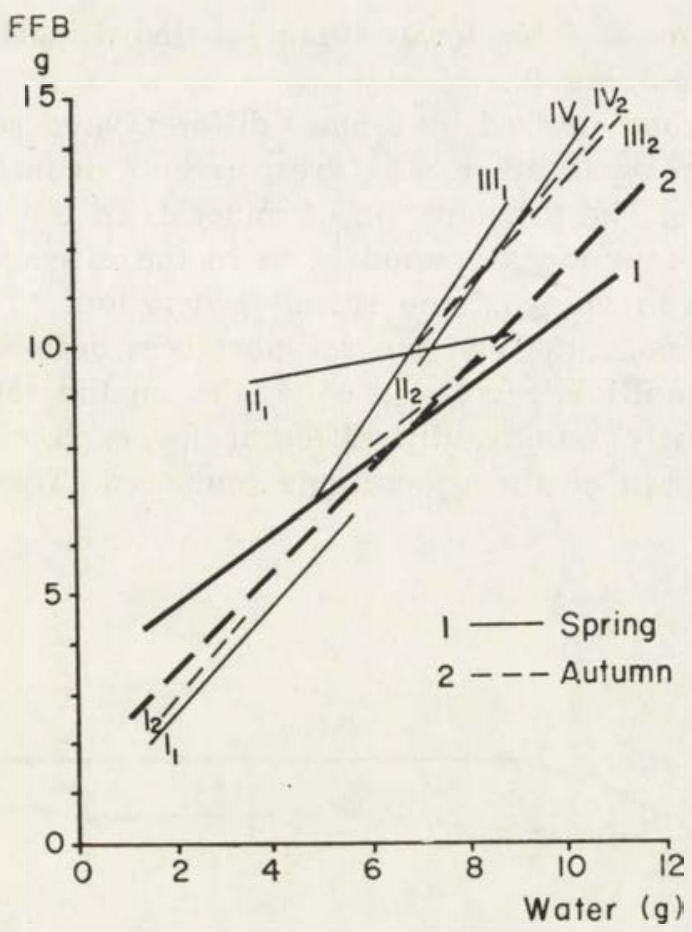

Fig. 4. Increase in fat-free body mass $(F F B)$ depending on rate of increase in body water, conditioned by simultaneous increase in protein and minerals.

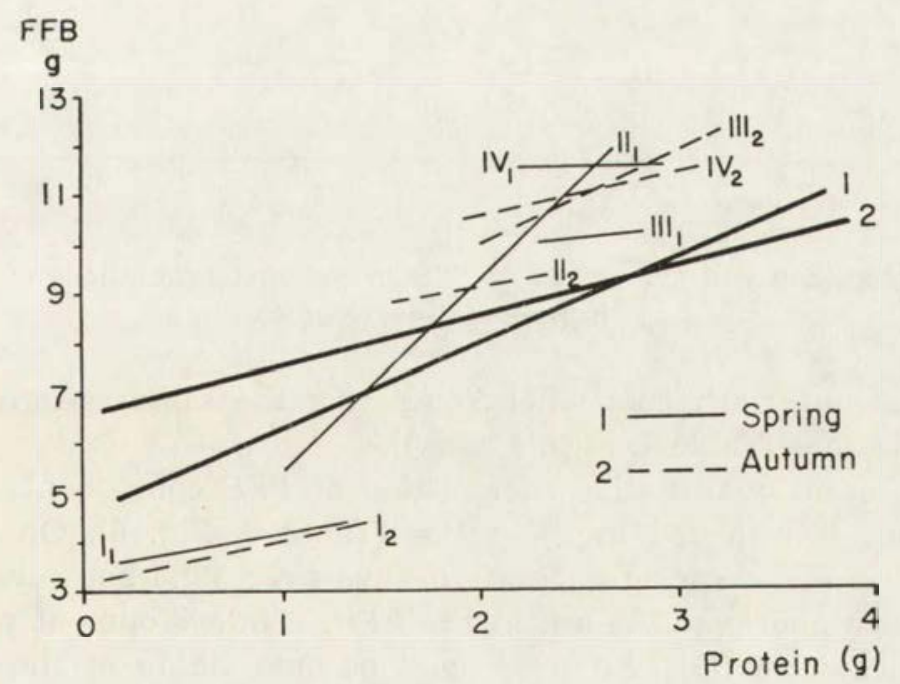

Fig. 5. Increase in fat-free body mass $(F F B)$ depending on rate of increase in protein, conditioned by simultaneous increase in body water and minerals. 
generation is almost $40 \%$ lower than in individuals of the spring generation (Table 5, Fig. 5).

Minerals are characterized by a more differentiated rate of accumulation. A unit increase in ash mass corresponds to an increase in $F F B$ by 0.20 to 3.00 units. The participation of minerals in the formation of the FFB during the four month period is, as in the case of participation of protein, greater in voles of the spring generation. The simultaneous influence of protein, water and mineral substances, defined mathematically in the form of multiple regression equations, on the rate of increase in $F F B$ is statistically significantly different for each of the periods of development within of the generations compared. These equations are

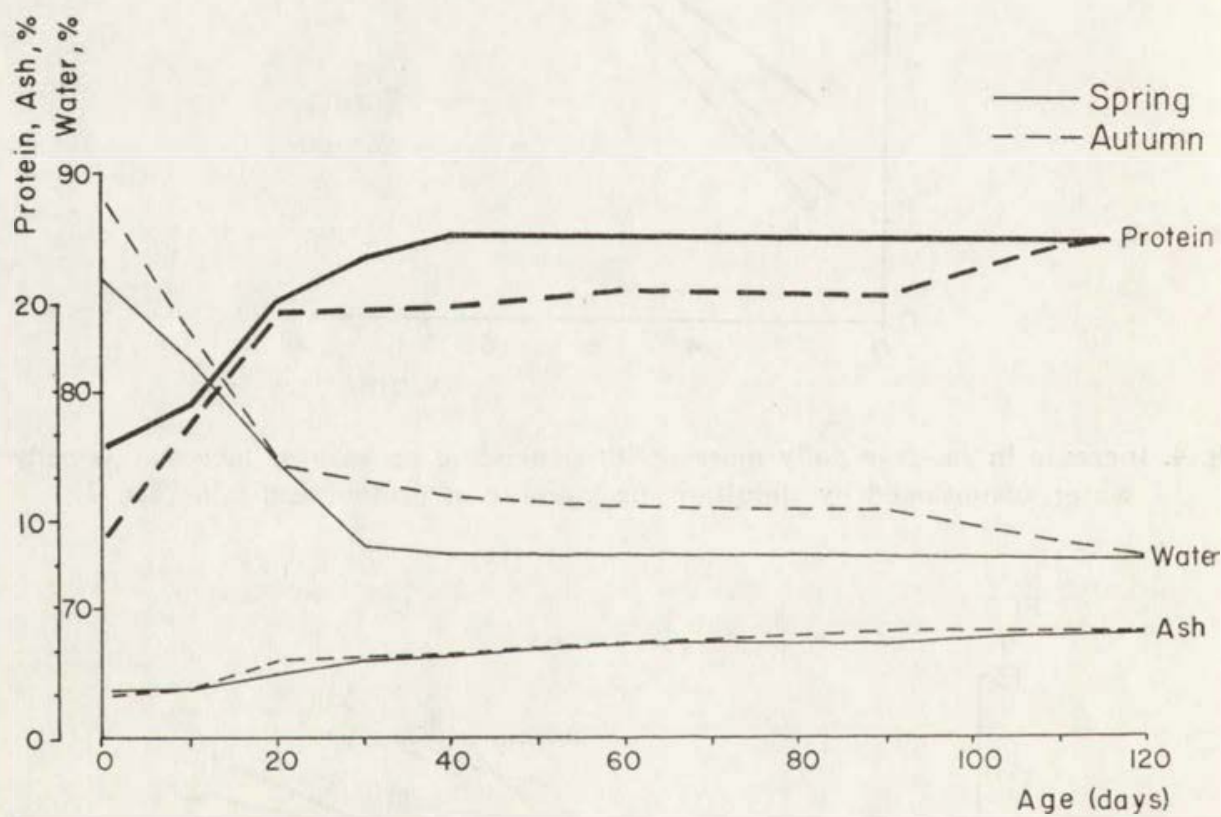

Fig. 6. Composition and percentage of FFB in seasonal generations of. C. glareous in postnatal development.

also significantly different when comparing the same age groups in the two generations (Table 4, Figs. 4 and 5).

The different quantitative composition of FFB components in the tvo generations is reflected in the ratios (Table 3, Fig. 6). On the day of birth, voles of the spring generation have over $85 \%$ body water, almist $12 \%$ protein and over $2 \%$ ash in the $F F B$. As development proceeds the level of water in the FFB drops and become stable at the age 35-40 days. Protein reaches a constant level at the same age. The level of minerals increases up to the 60 th day of life, then decreases slighty. 
These minimum differences in the percentage of ash content occuring between the 40 th and 90 th day of life may, however, be due to an error in the method used for determining minerals. It may therefore be assumed that voles of the spring generation reach chemical maturity at an age of 35 to 40 days.

As early as the day of birth voles of the autumn generation have different proportions of basic components in the fat-free body mass, from those in voles of the spring generation. They are characterized by a higher percentage of body protein and a lower percentage of body water. Until they reach chemical maturity, voles of the spring generation show a gradual decrease in the percentage of water and an increase in the percentages of protein and minerals in the $F F B$, in voles of the autumn generation however, the increase of protein and decrease of water gradually ceases during the third month of life (Table 3, Fig. 6). Hence 60 and 90-day old voles born at the end of the reproductive season have a very similar percentage of protein content in the FFB. Voles about 20 days old, belonging to the spring generation, are characterized by a similar body water level. Even greater differences between generations occur with respect to the proportions of body protein, the level of which in 20-, 40-, 60- and 90-day old voles of the autumn generation is almost identical, despite the increase in absolute values (Table 1). It is only the level of minerals which is similar in both generations.

Differences in the amounts of protein and water already existing in newborn animals of the seasonal generations and differences in the rate of increment of these components during development cause differences in physiological age. The process of physiological ageing continues uninterruptedly in voles of the spring generation from birth until they attain chemical maturity. Its rate decreases with age, e.g. during the first 10 days of life it is $50 \%$ higher than during the subsequent 10 days of life, and as much as 3.5 times higher than between the 20th and 30th day of life.

In bank voles of the autumn generation the process of physiological ageing is not a continuous process. During the first 20 days of life the average rate of ageing (protein/water/day) is higher in these animals than in voles of the spring generation. Between the 40th and 90 th day of life the average physiological age of voles belonging to the autumn generation is almost uniform - practically speaking there is an interval in physiological ageing. After an interval lasting about two months voles of this generation again begin to age in the fourth month of life until they reach chemical maturity. As a results of the different start in life and rate of physiological ageing, a day-old vole of the spring generation 
is comparable, from the physiological age aspect to a 5-day old individual of the autumn generation. Twenty-day old voles of the spring generation have a similar index of physiological age to that of two and three-month old voles of the autumn generation (Table 1). The relationship between physiological and absolute age and the mathematical picture of these relationships are given in Fig. 7. As a result of the generalization due to the mathematical character of the relationships analysed, differences in physiological age calculated from regression equations are different from

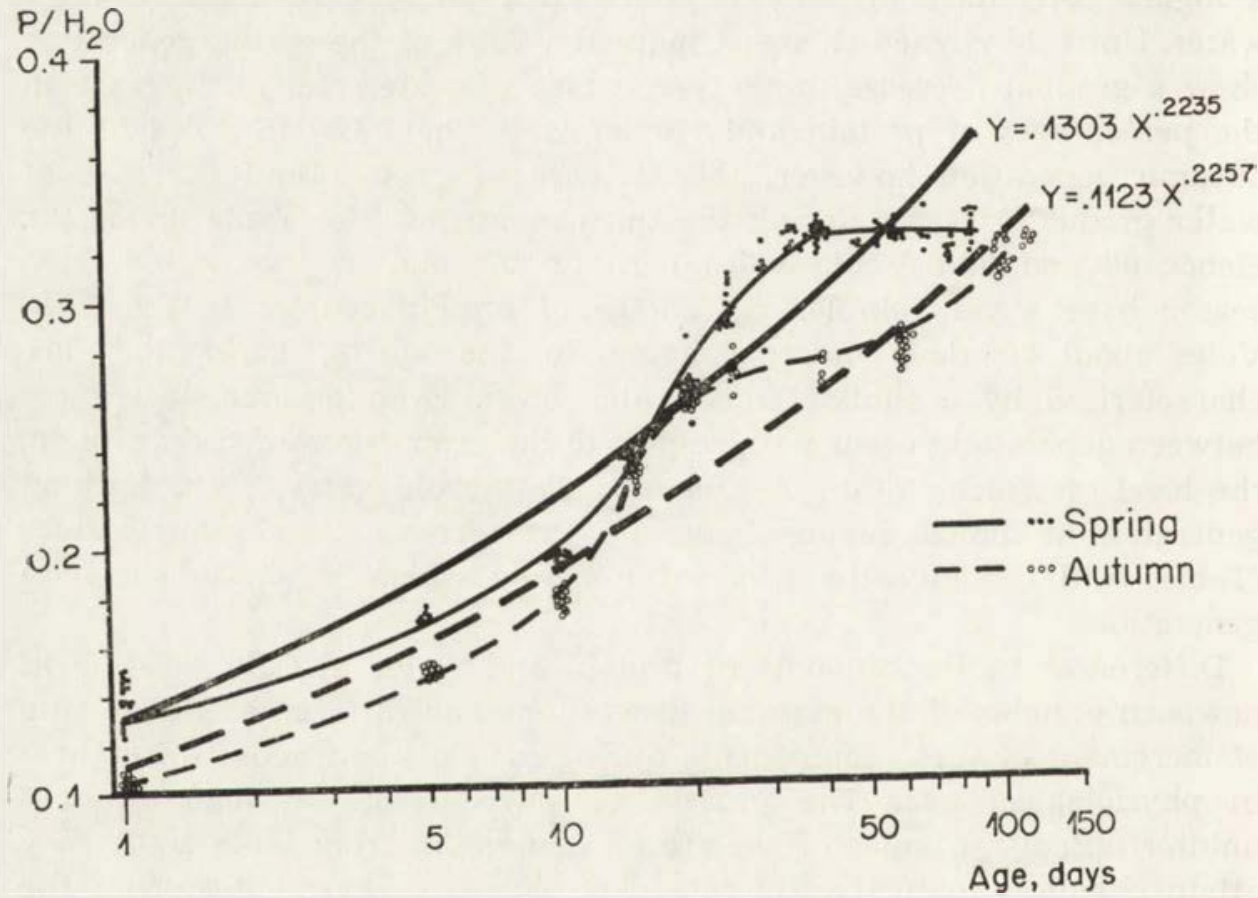

Fig. 7. Relation between absolute age and physiological age in seasonal generations of C. glareolus.

The thin S-shaped line indicates relations between the parameters examined on basis of interpolation. The thick line corresponds to mathematical relation of parameters.

those obtained when comparing the average index of physiological age for the given absolute age (for details see $\mathrm{F}$ e d y k, $1974 \mathrm{~b}$ ).

4. The Effect of Diet on Gross Body Composition in Bank Voles of the Spring Generation

The differences revealed in amounts and proportions of the gross body composition of voles of different seasonal generations suggested that a check should be made to ascertain whether at least one of the sources 
Table 6

Gross body composition in postnatal development of the spring generation of C. glareolus fed on died not containing grass. In vertical direction: in columns $1-6$ average values and standard deviation are given, coefficient of variation in brackets, in columns 7-9 average values in percentages of FFB components, and range of their variations in barckets.

\begin{tabular}{|c|c|c|c|c|c|c|c|c|c|c|}
\hline \multirow{2}{*}{$\begin{array}{l}\text { Age } \\
\text { days }\end{array}$} & \multirow{2}{*}{ Body weight } & \multirow{2}{*}{ Fat } & \multirow{2}{*}{ Water } & \multirow{2}{*}{ Protein } & \multirow{2}{*}{ Ash } & \multirow{2}{*}{ FFB } & \multicolumn{3}{|c|}{ Percentage of } & \multirow{2}{*}{$\begin{array}{c}\text { Protein: } \\
\text { Water }\end{array}$} \\
\hline & & & & & & & Water & Protein & Ash & \\
\hline & 1 & 2 & 3 & 4 & 5 & 6 & 7 & 8 & 9 & 10 \\
\hline 30 & $\begin{array}{c}10.261 \pm 1.147 \\
(11.2)\end{array}$ & $\begin{array}{c}1.113 \pm .265 \\
(23.8)\end{array}$ & $\begin{array}{c}6.961 \pm .861 \\
(12.4)\end{array}$ & $\begin{array}{c}1.8544 \pm .238 \\
(12.8)\end{array}$ & $\begin{array}{c}.322 \pm .050 \\
(15.5)\end{array}$ & $\begin{array}{l}9.141 \pm 1.126 \\
(12.3)\end{array}$ & $\begin{array}{c}76.1 \\
(76.1-76.2)\end{array}$ & $\begin{array}{c}20.3 \\
(20.0-20.5)\end{array}$ & $\begin{array}{c}3.5 \\
(3.3-3.6)\end{array}$ & $\begin{array}{l}.2666 \\
(.265-.269)\end{array}$ \\
\hline 35 & $\begin{array}{c}10.076 \pm 1.033 \\
(10.3)\end{array}$ & $\begin{array}{c}1.439 \pm .452 \\
(31.4)\end{array}$ & $\begin{array}{c}6.495 \pm .492 \\
(7.6)\end{array}$ & $\begin{array}{c}1.786 \pm .159 \\
(8.9)\end{array}$ & $\begin{array}{c}.347 \pm .024 \\
(7.0)\end{array}$ & $\underset{(7.7)}{8.628 \pm .665}$ & $\begin{array}{c}75.3 \\
(74.9-75.9)\end{array}$ & $\begin{array}{c}20.9 \\
(20.3-21.4)\end{array}$ & $\begin{array}{c}3.8 \\
(3.6-4.4)\end{array}$ & $\stackrel{.278}{(.275-.286)}$ \\
\hline 40 & $\begin{array}{c}11.575 \pm .834 \\
(7.2)\end{array}$ & $\underset{(17.4)}{1.895 \pm .332}$ & $\underset{(7.3)}{7.205 \pm .529}$ & $\begin{array}{c}2.062 \pm .161 \\
(7.8)\end{array}$ & $\begin{array}{c}.400 \pm .035 \\
(8.7)\end{array}$ & $\underset{(7.6)}{9.680 \pm} .733$ & $\begin{array}{c}74.4 \\
(74.3-74.6)\end{array}$ & $\begin{array}{c}21.3 \\
(21.1-21.4)\end{array}$ & $(4.0-4.3)$ & $\begin{array}{c}.286 \\
(.283-.289)\end{array}$ \\
\hline 50 & $\begin{array}{c}15.014 \pm .464 \\
(3.1)\end{array}$ & $\begin{array}{c}4.162 \pm .935 \\
(22.5)\end{array}$ & $\begin{array}{c}7.957 \pm .370 \\
(4.6)\end{array}$ & $\begin{array}{c}2.402 \pm .097 \\
(4.0)\end{array}$ & $.478 \pm .030$ & $\begin{array}{c}10.857 \pm .499 \\
(4.6)\end{array}$ & $\begin{array}{c}73.3 \\
(73.2-73.4)\end{array}$ & $\begin{array}{c}22.2 \\
(21.9-22.3)\end{array}$ & $\stackrel{4.4}{(4.3-4.5)}$ & $\stackrel{.302}{(.299-.303)}$ \\
\hline 60 & $\begin{array}{c}12.591 \pm 1.334 \\
(10.6)\end{array}$ & $\begin{array}{c}2.188 \pm .925 \\
(42.3)\end{array}$ & $\begin{array}{c}7.529 \pm .363 \\
(4.8)\end{array}$ & $\begin{array}{c}2.367 \pm .118 \\
\quad(5.0)\end{array}$ & $.465 \pm .026$ & $\begin{array}{c}10.403 \pm .503 \\
(4.8)\end{array}$ & $\begin{array}{c}72.6 \\
(72.3-72.9)\end{array}$ & $\begin{array}{c}22.7 \\
(22.6-23.0)\end{array}$ & $\begin{array}{c}4.5 \\
(4.3-4.6)\end{array}$ & $\stackrel{.313}{(.310-.316)}$ \\
\hline 70 & $\begin{array}{c}15.662 \pm 1.583 \\
(10.1)\end{array}$ & $\begin{array}{c}3.794 \pm 1.934 \\
(51.0)\end{array}$ & $\begin{array}{c}8.580 \pm 1.155 \\
(13.5)\end{array}$ & $\begin{array}{c}2.729 \pm .332 \\
(12.2)\end{array}$ & $\begin{array}{c}.547 \pm .068 \\
(12.5)\end{array}$ & $\begin{array}{c}11.868 \pm 1.558 \\
(13.1)\end{array}$ & $\begin{array}{c}72.4 \\
(71.9-72.8)\end{array}$ & $\begin{array}{c}23.3 \\
(22.6-23.8)\end{array}$ & $\stackrel{4.6}{(4.4-4.8)}^{4}$ & $\begin{array}{c}.318 \\
(.310-.327)\end{array}$ \\
\hline
\end{tabular}


of these differences was variation in diet. For this purpose the gross body composition in voles of the spring generation fed on a concentrated diet without the addition of grasses was determined (Table 6).

On the 30th day of life these voles differed considerably from voles of the spring generation fed on the same concentrated diet but with the addition of grass. They were fatter, had smaller amounts of protein, larger amounts of water and the composition in percentages of the FFB components was closer to voles of the autumn generation. On the 60th day of life they were, however, similar to voles of the spring generation with respect to the parameters analyzed.

Changes in the proportions of the $F F B$ components accompanying the development of voles deprived of green plant matter in their food take place continually, in the same way as voles of the spring generation fed on a normal diet. The rate of these changes was, however, different and therefore in relation to absolute age these voles reached chemical maturity between the 60th and 70th day of life. Voles subjected to the feeding experiment were physiologically younger between the 30 th and 70 th day of life that the other voles of the spring generation of corresponding age.

\section{DISCUSSION}

The generally known fact of differentiated growth in mammals also applies to the rate of increase in body mass, its various organs and tissues and also gross body composition (see review by S p r a y \& W idd ow s on, 1950).

The regularities relating to $G B C$ during the growth period have been most thoroughly investigated in laboratory animals. It has been shown that the differentiated increase in body mass is accompanied by a differentiated increase in protein, water and minerals. The rate of increase of these substances decreases with age (M o ulto n, 1923; C hanutin, 1931: B a ile y et al., 1960). Changes in the proportions of FFB components accompanying development are particularly characteristic the percentage of water gradually decreases, while that of protein and minerals increases. Changes in the proportions of FFB components continue until the time the organism reaches chemical maturity, which consist of a stabilization of the percentage level of water, protein and mineral substances in the FFB (Moulto n, 1923). The age at which an animal attains this maturity has been accepted as characteristic of the species (Widdows on \& Dickerson, 1960). A correlation was also observed between the longevity of mammals and the age at which they reach chemical maturity, calculatnig that this constitutes from $4-5 \%$ of the life span (M o u 1 t o $n, 1923$ ). 
The "mature body water level « has been used to describe a chemically mature animal, as this comes within narrow limits for many species of mammals: $72.8 \%$ for laboratory mice (B a i l e y et al., 1960), 73.2 for the rat, guinea pig, rabbit and monkey ( $\mathrm{Pace} \& \mathrm{R}$ a th b u n, 1945) and for man (Widdowson, McCance \& Spray, 1951) and $74.4 \%$ for pigs (Kraybill, Goode, Robertson \& Sloane, 1953).

The first $G B C$ studies in samples from populations of wild mammals have been concentrated chiefly on the problem of seasonal variation (H a y w a rd, 1965; Gór ecki, 1965; My r cha, 1969; Evans, 1973; $\mathrm{S}$ a wicka-Kapusta, 1974). It is only in $M$. arvalis and $C$. glareolus that $G B C$ has been studied in postnatal development ( $\mathrm{S} \mathrm{a} \mathrm{w} \mathrm{i} \mathrm{c} \mathrm{k} \mathrm{a-K} \mathrm{a-}$ pus ta, 1970; 1974).

In the present study it has been shown that the process of development of different seasonal generations of C. glareolus is accompanied by characteristic and significant changes in the amounts and proportions of FFB components and also by a different rate of fat accumulation. Bank voles of the extreme seasonal generations differ with respect to $G B C$ even on the day of birth. Differences in the rate of accumulation of FFB components in the generations compared were discovered by applying multiple regression equations to describe the quantitative relationships between the $F F B$ and its components at different stages of development. It has been shown here that rate of increase of one of the $F F B$ components is conditioned by the rate of increase of the remainder.

The differences revealed in the age at which voles attain chemical maturity show that it is impossible to speak of a characteristic age of attainment of this maturity in the case of cyclomorphic species. In addition, neither the average nor the maximun longevity of each of the generations correlates with the rate at which they attain chemical maturity in the way calculated by Moulton (cf. Schwarz et. al., 1964; P u c e k et al., 1969/70).

Although the stimulating effect of the length of photoperiod and green plant food in the diet of rodents on their rate of growth is well known (e.g. Pinter, 1968; Martinet \& Me unier, 1969; Martinet \& S pitz, 1971), it cannot be said that the lack of green plant food in the diet of voles of the spring generation prolongs the period they require to reach chemical maturity, since the effect of diet with the addition of spring grasses on the rate at which voles of the autumn generation attain chemical maturity was not investigated. In addition the assumption cannot be ruled out that parents of voles used for the nutrition experiment were voles of the spring generation, which were born in the early spring and began reproduction at the end of May. As the voles used for the nutrition experiment were not analyzed for gross body composition 
during the first 25 days of their life, it is not possible to establish whether the lack of green plant material in the food of young animals contributed to a different percentage composition of their $F F B$ during the period from the 30 to 70 th day of life, or whether these changes should be attributed to an indirect influence through the mother's milk. It is also impossible to explain the intermediate rate, in relation to the seasonal generations, of changes in proportions and amounts of the FFB components of laboratory-bred bank voles ( $\mathrm{F}$ e d y k, 1974 a) by differences in length of photo-period. The development rate of these voles does not depend on the lenght of the photoperiod or on seasonal differences in the composition of the food, as voles born in spring and also late in the autumn had a uniform ratio of $F F B$ components at a comparable age.

The mature body water level unequivocally describes both extreme generations of bank voles, but does not describe the species. Chemically mature voles from a different part of Poland (Niepołomice Forest) are characterized by a higher percentage content of water in the FFB than voles from Białowieża (cf. S a w i ck a-K a p u s t a, 1974).

$\mathrm{B}$ a il e y et al. (1960) consider that the age at which an animal reaches chemical maturity marks the end of the continued increase in $F F B$, as the percentage composition of the $F F B$ in older animals is stable. In their opinion the later increase in body weight is due to fat, but this is refuted by data obtained in the present study and also by $G B C$ and histological studies made on rats (Lesser, Deutsch \& Markofsky, 1970). After chemical maturity is attained the FFB continues to increase and this growth is due to the increase of all components, without changes in proportion. Conclusions reached on the strength of differences in percentage proportions do not always relate to biological differences (see Miller \& W eil, 1963) but are often due only to the mathematical character of the relations examined (see review by $\mathrm{G}$ a $\mathrm{r}$, 1963) and are thus mathematical regularities. On this account the seasonal variations in body water in rodent and insectivore bodies ( $\mathrm{G}$ órecki, 1965; Myrcha, 1969; S awicka-Kapusta, 1974) should be re-examined, particularly in view of the fact that seasonal changes in body weight have been explained by changes in amount and ratio of body water (My r cha, 1969). Conclusions are drawn as to seasonal changes in body water on the basis of comparisons of the percentage composition of the body or average body weights and gross body composition in sample individuals taken from populations at different seasons. It is known, however, that the amount of fat in an organism is synchronized with climatic conditions and its periodical losses affect the proportions of other components. It is for this reason that FFB or lean dry weight $(L D W)$ has for a long time been accepted as the basis for 
all comparisons. Body water, expressed in percentages in relation to $L D W$, is not subject to variation during the yearly cycle, despite seasonal differences in its absolute values ( $\mathrm{E} \vee$ ans, 1973). The finding of statistically significant differences in absolute values of body water content in samples from different seasons is not necessarily the consequence of periodical water loss by the organism, but only the result of a smaller water content in the whole sample, which may for instance be conditioned by a lack of uniformity in the age composition of the samples from the population.

The discovered differences in the rate of physiological ageing and attainment of chemical maturity are correlated with the earlier established morphological characters and parameters, connected with the biology of the generations. Bank voles of the spring generation which attain chemical maturity about the 40 th day of life are characterized by a rapid growth rate, attain sexual maturity quickly and are more fecund than voles of the autumn generation. The latter take three times longer to reach chemical maturity, have inhibited growth during the winter and become sexually mature in the following 'calendar year (cf. N ew son, 1963, B ergstedt, 1965; Z e jda, 1966; Cla ude, 1970; Tupikova \& Konovalova, 1971).

The development and biology of extreme litters from one reproductive season are so closely synchronized with the cyclic changes in habitat conditions that it would appear that there is a "specific metamorphosis of generations « in cyclomorphic species as the result of which, if indeed the characters differentiating generations are inherited, the characters of the grandparents are inherited. Inheritance of characters not in the first, but the second generation, would be the basis of the maintenance of a cyclic interchangeability of phenotypes with different morphological, physiological and behavioural characters. The simplified diagram of the interchange of generations would thus appear as follows: the spring reproductive basis of the population, consisting mainly of animals born at the end of the previous reproductive season, begins reproducing and produces numerous quickly growing and quickly maturing progeny - the spring generation. Individuals of this generation crossbreed with each other and their progeny, equipped with the grandparents' characters (slow growth, maturation in the following calendar year), form the basis of the overwintering population which begins reproducing in spring. This scheme does not exclude the possibility of crossbreeding between generations, e.g., intermediate between phenotypes.

The data on age structure and the relationships between generations in many species of rodents obtained by Schwa r z et al. (1969/70) show that an interchange of generations may take place in natural populations 
of rodents. Generations I and II distinguished by the autors in Apodemus agrarius in fact constitue one generaiton $F_{1}$ (in relation to old adults), while the great majority of individuals in generations IV and V, which begin to overwinter and take part in reproduction during the subsequent calendar year, is generation $F_{2}$ in relation to old adults (see Fig. 8).

Owing to the different length of ecological life characterizing succesive generations, and as a result of the spatial structurs of the species, crossbreeding takes place chiefly within generations. According to $\mathrm{Schw}$ a $\mathrm{z}$ et al. (l.c) crossbreeding also takes place between generations $\left(P \times F_{1}\right)$ but it is limited to contacts between old adult males and their daughters. Male $F_{1}$ reach sexual maturity later than their sisters. It

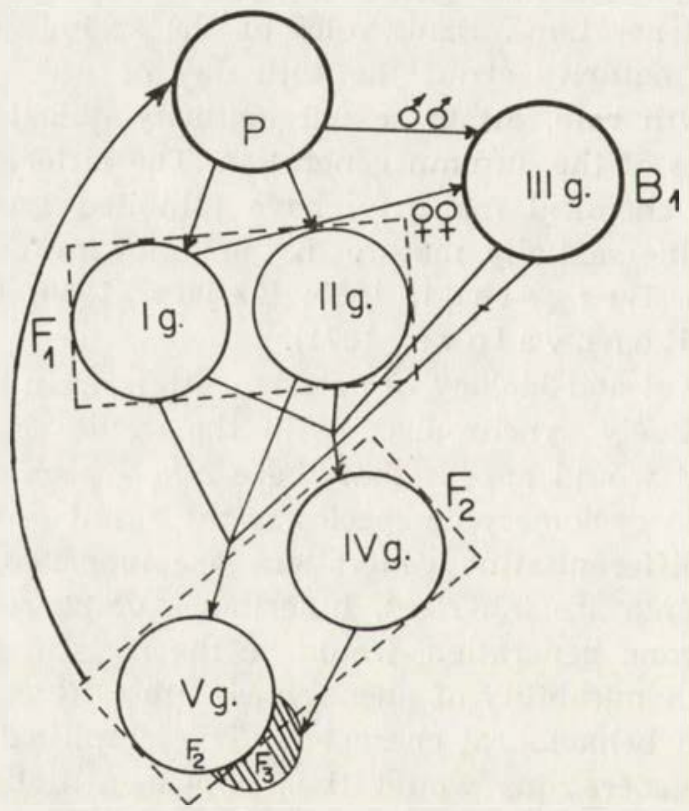

Fig. 8. Diagram showing interchange of generations in Apodemus agrarius on basis of data given by S chwarz et al., 1969/70.

appears likely that behavioural differences also play an important role in limiting contacts between generations. There are data forming evidence of the existence of antagonism between settled old adult males and the current year's males (Chit ty \& P hipps, 1966). The old males do not allow the young to enter the areas they themselves frequent and the young males are therefore obliged to emigrate from the area which forms the winter shelter of the species and return after the death (natural or violent) of the old adults. The chances of crossbreeding between old 
adults of the given calendar year and old adults which took part in reproduction the previous year are very small.

Characters such as body weight, growth, matabolism etc. are quantitative characters. The regularities in inheritance of these characters were ascertained under artificial breeding conditions in which guided selection was applied. There are no data on inheritance of quantitative characters in natural populations of wild rodents and the possibility of inheriting a group of characters not in the first but in the second generation is doubtful. Probably the cause of the differentiation revealed is the cyclically changing habitat. It has however, been found that experimental changes in length of photoperiod and presence or lack of green plant food in the diet do not affect changes in rate of growth of young animals born over the course of a year, neither do they affect seasonal changes in body weight in adult males (Pokrovski \& Ovtchinnikova, 1967).

It will only be possible to establish whether the rate of changes in body composition and other characters differentiating seasonal generations of cyclomorphic rodents are hereditary, or whether they depend on habitat factors, after the inheritance of these characters and the effect of the habitat have been studied.

Acknowledgements: I should like to offer my thanks to Professor Z. P u ce k and Dr. M. Gębczynski for their assistance in the preparation of the text, to Mrs. E. M a $1 \mathrm{z}$ a h n, M. Sc., for her unfailing assistance with the experiments and members of the Calculations Section of the Polish Academy of Sciences Computer Centre in Warsaw for carrying out a considerable part of the statistical calculations. Thanks are also due to Mr. T. H e a ling, M. Sc., Department of Zoology, Royal Holloway College, for revising the English text.

\section{REFERENCES}

1. A damczewska K. A, 1961: Intensity of reproduction of the Apodemus flavicollis (Melchior, 1834) during the period 1954-1959. Acta theriol., 5: $1-21$.

2. Adamczewska-Andrzejewska K. A., 1971: Methods of age determination in Apodemus agrarius (P a 11 a s, 1971). Ann. Zool. Fennici, 8: 68-71.

3. Amstislavskaja T. S., 1970: Dinamika mitotičeskoj aktivnosti v pokrovnyh tkaniah polevki Clethrionomys glareolus raznych sezonnyh generacji. Ekologija, 4: $68-74$.

4. Anders on P. K., 1970: Ecological structure and gene flow in small mammals. Symp. zool. Soc. Lond., 26: 299-325.

5. Bailey C. B., Kitts W. D. \& Wood A. J., 1960: Changes in the gross chemical composition of the mouse during growth in relation to the assessement of physiological age. Can. J. Anim. Sci., 40: 143-155.

6. B erg stedt B., 1965: Distribution, reproduction, growth and dynamics of the rodent species Clethrionomys glareolus ( $\mathrm{S} \mathrm{chreber}$ ), Apodemus flavicollis 
(M elchior) and Apodemus sylvaticus (L in né) in Southern Sweden. Olkos, 16: $132-160$.

7. Borowski S. \& Dehnel A., 1953: Materialy do biologii Soricidae. Annls. Univ. M. Curie-Skłod. Lublin, sect. C, 7: 305-448.

8. Chanutin A., 1931: The influence of growth on a number of constituents of the white rat. J. biol. Chem., 93: $31-37$.

9. Chitty D. \& Phipps E., 1966: Seasonal changes in survival in mixed populations of two species of vole. J. anim. Ecol., 35: 313-331.

10. Claude C., 1970: Biometric und Fortpflanzungsbiologie der Rötelmaus Clethrionomys glareolus (S $\mathrm{chreber}, 1780$ ) auf verschiedenen Höhenstufen der Schweiz. Rev. suisse Zool., 77: 435-480.

11. Crawley M. C., 1970: Some population dynamics of bank vole, Clethrionomys glareolus and wood mouse, Apodemus sylvaticus in mixed woodland. J. Zool., 160: $1-89$.

12. Dehnel A., 1949: Badania nad rodzajem Sorex L. Annls. Univ. M. Curie-Skłod. Lublin, sect. C, 4: 17-97.

13. De hn el A., 1950: Badania nad rozwojem Neomys Kaup. Annls. Univ. M. Curie-Skłod. Lublin, sect, C. 5: $1-63$.

14. Elandt R., 1964: Statystyka matematyczna w zastosowaniu do doświadczalnictwa rolniczego. Państw. Wyd. Nauk.: $1-595$. Warszawa.

15. Evan S D. M., 1973: Seasonal variations in the body composition and nutrition of the vole Microtus agrestis. J. Animal Ecol., 43: 1-18.

16. Fedyk A., 1974 a: Gross body composition in postnatal development of the bank vole. I. Growth under laboratory conditions. Acta theriol., 19, 26: 381-401.

17. Fedyk A., 1974 b: Gross body composition in postnatal development of the bank vole. III. Estimating age. Acta theriol., 19: 429-440.

18. Fleharty E. D., Krause M. E. \& Stinnet D. P., 1973: Body composition, energy content and lipid cycles of four species of rodents. J. Mammal., 54: $426-438$.

19. Garn S. N., 1963: Some pitfals in the quantifications of body composition. Ann. N. Y. Acad. Sci., 110: 171-174

20. Gliwicz J., Andrzejewski R., Bujalska G. \& Petrusewicz K., 1968: Productivity investigation of an island population of Clethrionomys glareolus (S chreber, 1780). I. Dynamics of cohorts. Acta theriol., 13: 401-413.

21. Górecki A., 1965: Energy values of body in small mammals. Acta theriol., 10: $333-352$.

22. H a y ward J. S., 1965: The gross body composition of six geographic races of Peromyscus. Can. J. Zool., 43: 297-308.

23. Hyvärinen H. \& Heikura K., 1971: Effects of age and seasonal rythm on the growth patterns of some small mammals in Finland and in Kirkenes, Norway. J. Zool., Lond., 165: 545-556.

24. Kaikusalo A,, 1972: Population turnover and wintering of the bank vole, Clethrionomys glareolus (Schreb.), in Soutern and Central Finland. Ann. Zool. Fennici, 9: 219-224.

25. Kraybill H. F., Bitter H. L. \& Hankins O. G., 1952: Body composition of cattle. II. Determination of fat and water content from measurements of body specific gravity. J. Appl. Physiol., 4: 575-583.

26. Ku bik J., 1965: Morphological variability of the population of Clethrionomys glareolus. Acta theriol., 10: 117-179.

27. Lesser G. T., Deutsch S. \& Markofsky J., 1970: The rat fat-free 
body in middle life - continuing growth and histochemical changes. J. Gerontol., 25: $108-114$.

28. Marszałkowicz T., 1962: Statystyka teoretyczna. Wyd. S.G.G.W.: 1-204. Warszawa.

29. Martinet L. \& Meunier M., 1969: Influence des variations saisonnieres de la luzerne sur la croissance, la maturité et l'etablissement de la maturité sexuelle chez le campagnol des champs (Microtus arvalis). Ann. Biol. anim. Biochem. Biophys., 9: 451-462.

30. Martinet L. \& Spitz F., 1971: Variations saisonnieres de la croissance et de la mortalité du campagnol des champs Microtus arvalis. Role du photoperiodisme et de la vegetation sur ces variations. Mammalia, 35: $38-84$.

31. Miller I. \& Weil W. B. Jr., 1963: Some problems in expressing and comparing body composition determined by direct analysis. Ann. N. Y. Acad. Sci., 110: 153-160.

32. Moult on C. R., 1923: Age and chemical development in mammals. J. biol. Chem., 57: 79-97.

33. Myrcha A., 1969: Seasonal changes in caloric value, body water and fat in some shrews. Acta theriol., 14: 211-227.

34. News on R., Differences in numbers, reproduction and survival between two neigboring populations of bank voles (C. glareolus). Ecology, 44: 110-120.

35. Olenev V. G., 1964: Sravnitel'nyj analiz sezonnyh izmenenij morfo-fizjologičeskih pirnzakov polevoj i lesnoj myši. [In: „Voprosy vnutrividovoj izmenčivosti nazemnyh pozvonoěnyh i mikroevolucija «]: 91-93. Sverdlovsk.

36. P a ce N. \& R a th bun E. N., 1945: Studies on body composition. III. The body water and chemically combined nitrogen content in relaiton to fat content. J. Biol. Chem., 158: 685-691.

37. P inter A. J., 1968: Effects of diet and light on growth, nutrition and adrenal size of Microtus montanus. Amer. J. Physiol., 215: 461-466.

38. Pokrovski A. V., 1966: Sezonnye kolebanija vesa tela u polevok. Trudy Inst. Biol., Sverdlovsk, 51: 95-106.

39. Pokrovski A. V., 1967: Skorost' rosta molodniaka polevok v zavisimosti ot vremeni roždenija. Trudy Mosk. obšc. Isp. Prirody, 25: 85-86.

40. Pokrovski A. V., 1971: Seasonal changes in biological cycles in some rodents and the problem of absolute age determination. Ann. Zool. Fennici, 8: 94-96.

41. Pokrovski A. V. \& Ovtschinnikova N. A., 1967: Vlijanije osveščenija i racjona nekotoryh biologiceskih ciklov u polevok. Trudy Mosk. obšč. Isp. Prirody, 25: 87-90.

42. Pucek Z., Ryszkowski L. \& Zejda J., 1969/70: Estimation of average lenght of life in bank vole, Clethrionomys glareolus ( $\mathrm{S} \mathrm{ch} \mathrm{reber,} \mathrm{1780).} \mathrm{[In:}$ "Energy flow through small mammal populations Eds.: Petrusewicz K. \& Ryszkowski L.]. Państw. Wyd. Nauk.: 187-201. Warszawa.

43. Sawicka-Kapusta K., 1970: Changes in the gross body composition and caloric value of the common voles during their postnatal development. Acta theriol., 15: 67-79.

44. Sawicka-Kapusta K., 1974: Changes in the gross body composition and energy value of the bank vole during their postnatal development. Acta theriol. 19: 27-54.

45. Schwarz S. S., Pokrovski A. V., Istchenko V. G., Olenjev V. G., Ovtschinnikova N. A. \& Pjastolova O. A., 1964: Biological pecularities 
of seasonal generations of rodents, with special reference to the problem of senescence in mammals. Acta theriol., 8: $11-43$.

46. Schwarz S. S., Bol'shakov V. N., Olenev V. G. \& Pjastolova O. A., 1969/70: Population dynamics of rodents from northern and moutainous geographical zones. [In: "Energy flow through small mammal populationse. Eds.: Petrusewicz K. \& Ryszkowski L.]. Państw. Wyd. Nauk.: 187-201. Warszawa.

47. Spra y C. M. \& Widdows on E. M., 1950: The effect of growth and development on the composition of mammals. Brit. J. Nutr., 4: 332-360.

48. Tupikova N. V. \& Konovalova E. A., 1971: Razmnoženije i smertnost' ryžih polevok v južnotaežnyh lesah vjatsko-kamskogo mezdurečija. Mater. Pozn. Fauny Flory SSSR, 46, Fauna i ekologija gryzunov, 10: 145-186.

49. Widdowson E. M., McCance R. A. \& Spray C. M., 1951: Chemical composition of the human body. Clin. Sci., 10: 113-125.

50. Widdows on E. M. \& Dickerson J. W. T., 1960: The effect of growth and function on the chemical composition of soft tissues. Biochem. J., 77: $30-43$.

51. Zejda J., 1966: Litter size in Clethrionomys glareolus (Sch reber, 1780). Zool. Listy, 15: 193-204.

52. Z e j d a J., 1971: Differential growth of three cohorts of the bank vole, Clethrionomys glareolus, S c h r e b, 1780. Zool. Listy, 20: 229-245.

Accepted, May 30, 1974.

Mammals Research Institute, Polish Academy of Sciences, 17-230 Białowieża, Poland.

Anna FEDYK

\section{PODSTAWOWE SKÆADNIKI CIA£A W ROZWOJU POSTNATALNYM NORNICY RUDEJ. \\ II. ZROŻNICOWANIE GENERACJI SEZONOWYCH}

\section{Streszczenie}

Zbadano zmiany $\mathrm{w}$ tempie przyrostu oraz $\mathrm{w}$ proporcjach podstawowych składników ciała, towarzyszące rozwojowi generacji wiosennej i jesienniej C. glareolus, a także tempo uzyskiwania przez przedstawicieli tych generacji dojrzałości chemicznej.

Nornice skrajnych generacji, stanowiące pierwsze pokolenie urodzone w warunkach hodowli, już w dniu urodzenia mają różną zawartość tluszczu (Tabela 1). W toku rozwoju, w ciągu pierwszych czterech miesięcy życia, przeciętne tempo odkładania się tłuszczu jest wyższe u nornic generacji jesiennej. Matematyczne zależności między ciężarem ciała a otłuszczeniem są istotnie różne również przy porównywaniu krótszych odcinków rozwoju obydwu generacji jak tė w obrębie jednej generacji (Tabela, 2 Ryc. 3).

Różnie kształtuje się także ilościowy udział wody, białka i substancji mineralnych, wchodzących w skład beztłuszczowej masy ciała (FFB) (Tabela 4 i 5 , Ryc. 4 i 5). Odmienny skład ilościowy komponentów FFB znalazł swoje odbicie w stosunkach procentowych (Tabela 3, Ryc. 6). W miarę rozwoju nornic generacji wiosennej - aż do osiągnięcia dojrzałości chemicznej - zmniejsza się procentowa zawartość wody 
a zwiększa się procentowa zawartość białka i substancji mineralnych. Nornice tej generacji osiągają dojrzałość chemiczną około 40 dnia życia. Nornice generacji jesiennej już w dniu urodzenia mają odmienny skład procentowy komponentów FFB $i$ inne jest $u$ nich tempo zmian rozwojowych. Np. poziom białka pozostaje prawie jednakowy między 20 a 90 -tym dniem życia. Nornice generacji jesiennej osiągają dojrzałość chemiczną około 120 dnia życia, czyli w terminie trzy razy dłuższym niż nornice generacji wiosennej.

Różnice w ilości białka i wody, istniejące już u noworodków generacji sezonowych oraz zróżnicowania w tempie przyrostu tych składników w trakcie rozwoju, spowodowały różnice $w$ wieku fizjologicznym. Proces fizjologicznego starzenia się, którego miernikiem jest indeks wieku fizjologicznego, trwa u nornic generacji wiosennej nieprzerwanie - od urodzenia do osiągnięcia dojrzałości chemicznej. Natomiast średni wiek fizjologiczny nornic generacji jesiennej jest prawie jednakowy między 40 a 90 dniem życia. W wyniku różnego tempa fizjologicznego starzenia się, jednodniowa nornica generacji wiosennej, pod względem wieku fizjologicznego odpowiada pięciodniowej nornicy generacji jesiennej. Natomiast podobnym wskaźnikiem wieku fizjologicznego do dwu- i trzymiesięcznych nornic generacji jesiennej charakteryzują się dwudziestokilkudniowe nornice generacji wiosennej.

Wykazane różnice generacyjne w wieku, w którym nornice osiągają dojrzałość chemiczną, korelują z wcześniej poznanymi cechami morfologicznymi i parametrami związanymi z biologią generacji. Jednocześnie zaś świadczą o tym, ze w odniesieniu do gatunków cyklomorficznych nie można mówić o charakterystycznym dla gatunku wieku osiągania tej dojrzałości. Przeciętna ani maksymalna długość życia każdej z generacji nie korelują z tempem uzyskiwania przez nie dojrzałości chemicznej w sposób obliczony wcześniej dla innych ssaków. 